\title{
The sensitivity of dimethyl sulfide production to simulated climate change in the Eastern Antarctic Southern Ocean
}

\author{
By ALBERT J. GABRIC ${ }^{*}$, ROGER CROPP ${ }^{1}$, TONY HIRST ${ }^{2}$ and HARVEY MARCHANT ${ }^{3},{ }^{1}$ School of \\ Australian Environmental Studies, Griffith University, Nathan, 4111, Australia; ${ }^{2}$ CSIRO Atmospheric Research, \\ Private Bag 1, Aspendale, 3195, Australia; ${ }^{3}$ Australian Antarctic Division, Channel Highway, Kingston,
} Tasmania 7050 Australia

(Manuscript received 17 July 2002; in final form 15 April 2003)

\begin{abstract}
Dimethyl sulfide (DMS) is a radiatively active trace gas produced by enzymatic cleavage of its precursor compound, dimethyl sulfoniopropionate (DMSP), which is released by marine phytoplankton in the upper ocean. Once ventilated to the atmosphere, DMS is oxidised to form non-sea-salt sulfate and methane sulfonate (MSA) aerosols, which are a major source of cloud condensation nuclei (CCN) in remote marine air and may thus play a role in climate regulation. Here we simulate the change in DMS flux in the Eastern Antarctic ocean from 1960-2086, corresponding to equivalent $\mathrm{CO}_{2}$ tripling relative to pre-industrial levels. Calibration to contemporary climate conditions was carried out using a genetic algorithm to fit the model to surface chlorophyll from the 4-yr SeaWiFs satellite archive and surface DMS from an existing global database. Following the methodology used previously in the Subantarctic Southern Ocean, we then simulated DMS emissions under enhanced greenhouse conditions by forcing the DMS model with output from a coupled atmospheric-ocean general circulation model (GCM). The GCM was run in transient mode under the IPCC/IS92a radiative forcing scenario. By 2086, the change simulated in annual integrated DMS flux is around 20\% in ice-free waters, with a greater increase of $45 \%$ in the seasonal ice zone (SIZ). Interestingly, the large increase in flux in the SIZ is not due to higher in situ production but mainly because of a loss of ice cover during summer-autumn and an increase in sea-to-air ventilation of DMS. These proportional changes in areal mean flux $(25 \%)$ are much higher than previously estimated for the Subantarctic Southern Ocean (5\%), and point to the possibility of a significant DMS-climate feedback at high Southern latitudes. Due to the nexus between ice cover and food-web structure, the potential for ecological community shifts under enhanced greenhouse conditions is high, and the implications for DMS production are discussed.
\end{abstract}

\section{Introduction}

Dimethyl sulfoniopropionate (DMSP) is an organic sulfur compound produced by marine phytoplankton, although only certain species are significant producers (Keller et al., 1989). DMSP is enzymatically cleaved to dimethyl sulfide (DMS), which is released to oceanic surface waters in concentrations which are high enough to sustain a net flux to the atmosphere, currently estimated to be $0.75 \pm 0.3 \mathrm{Tmol} \mathrm{S} \mathrm{yr}^{-1}$

\footnotetext{
${ }^{*}$ Corresponding author. e-mail: a.gabric@griffith.edu.au
}

(Kettle and Andreae, 2000). Recent advances suggest that rather than being a function of algal taxonomy or standing stock, DMS concentration in the upper ocean is controlled by the dynamics of the entire marine pelagic food web (Kiene and Bates, 1990; Leck et al., 1990; Levasseur et al., 1996; Simo, 2001)

After ventilation to the atmosphere, DMS is oxidised to form non-sea-salt sulfate (nss- $\mathrm{SO}_{4}^{2-}$ ) and methane sulfonate (MSA) aerosols and is the major source of cloud condensation nuclei $(\mathrm{CCN})$ in unpolluted marine atmospheres such as the Southern Ocean (Ayers and Gras, 1991). Because the microphysical properties of clouds are sensitive to $\mathrm{CCN}$ 
concentration in the atmosphere, it has been postulated (Shaw, 1983; Charlson et al., 1987; Meszaros, 1988) that biological regulation of the Earth's radiation budget is possible through a DMS-CCN-cloud albedo link. Recent attempts at estimating magnitude of the DMS-climate feedback (Foley et al., 1991; Lawrence, 1993) suggest the likelihood of a small, negative feedback (stabilizing), with magnitude of order $10 \%$, and considerable uncertainty. Modelling analyses by Gabric et al. $(1998 ; 2001)$ in the Subantarctic Southern Ocean $\left(41-53^{\circ} \mathrm{S}\right)$ predicted the magnitude of the feedback to be less than $10 \%$.

It has been suggested the carbon and sulfur biogeochemistry in the Southern Ocean is particularly susceptible to changes due to global warming (Sarmiento et al., 1998). Martin (1992) hypothesized that past fluctuations in atmospheric $p \mathrm{CO}_{2}$ levels were due to feedback loops. between the carbon, iron and sulfur cycles. Contemporary evidence for such a coupling of the elemental cycles was presented by Gabric et al. (2002), who reported significant correlation between satellite-derived surface chlorophyll and atmospheric aerosol depth in the Subantarctic Southern Ocean.

Here we investigate the effect of simulated climate change on the sea-to-air flux of DMS in a region (Fig. 1) of the Eastern Antarctic Ocean, which overlaps with the site of a recent biological field survey. Although sparse, field measurements in the Antarctic ocean suggest that high DMS concentrations are possible during summer (Kettle et al., 1999). Elevated water concentrations, combined with high mean wind speeds, lead to the sea-to-air flux of DMS between $50-70^{\circ} \mathrm{S}$ being estimated as between 6 and $10 \%$ of the global total (Kettle and Andreae, 2000).

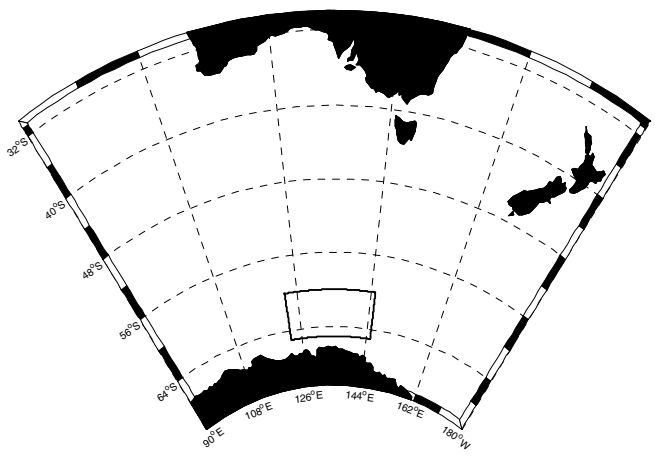

Fig. 1. The Southern Ocean study region used for the model simulations.
To gauge the impact of warming on biogenic sulfate emissions we have employed a full global oceanatmosphere GCM that has been run in transient mode using the same IPCC/IS92a radiative forcing scenario which was used in Gabric et al. (2001). This provides a detailed representation of the changes in the upper ocean in our study region under enhanced greenhouse conditions. The DMS production model was calibrated using satellite chlorophyll and archival field data on DMS for contemporary climate conditions. The model was then run using the GCM predicted forcings for the periods 1961-1970 (baseline), 2030-2039 (equivalent doubling of pre-industrial $\mathrm{CO}_{2}$ ) and 2078-2086, the time of approximate equivalent $\mathrm{CO}_{2}$ tripling relative to pre-industrial levels.

\section{Characteristics of study area}

Our study region extends from $60-65^{\circ} \mathrm{S}, 125-140^{\circ} \mathrm{E}$ in the Antarctic Southern Ocean, and includes part of the region sampled in a major biological study (BROKE: Baseline Research on Oceanography, Krill and the Environment) in the austral summer of 19951996 (Wright and van den Enden, 2000). The longitudinal extent of the study region was chosen to match that in our earlier Subantarctic study (Gabric et al., 2001). Long-term meteorological data are summarised in Fig. 2. The sea-surface temperature (SST) data is from Pathfinder AVHRR dataset (1985-1999), with values in range -1.8 to $2.1^{\circ} \mathrm{C}$. The PAR data were obtained from the Sea-viewing Wide Field-of-View (SeaWiFS) sensor (Lewis, 1995) 8-d archive (1997-2001). Wind speed data are from the QuickSCAT SeaWinds, (1999-2001) archive, with values high throughout the year $\left(\sim 10 \mathrm{~m} \mathrm{~s}^{-1}\right)$. Mixed layer depths are from the Levitus World Ocean Atlas (Boyer and Levitus, 1994) and compare well with the values measured during the BROKE survey $(48-70 \mathrm{~m})$. All the meteorological data were smoothed to avoid numerical integration problems. Figure 2 also shows monthly mean icecover data from the Special Sensor Microwave Imager (SSMI) at latitudes of $65-67^{\circ} \mathrm{S}$ for $10 \mathrm{yr}$ (1992-2001). Of note is the particularly strong spatial gradient and high variance in summer ice cover within the study region.

Field observations in the eastern Antarctic show that a short-lived spring-summer bloom event is typical of these waters (El-Sayed, 1988; Skerratt et al., 1995); however, there can be high interannual variability in the timing and magnitude of the bloom (Marchant 
(a)
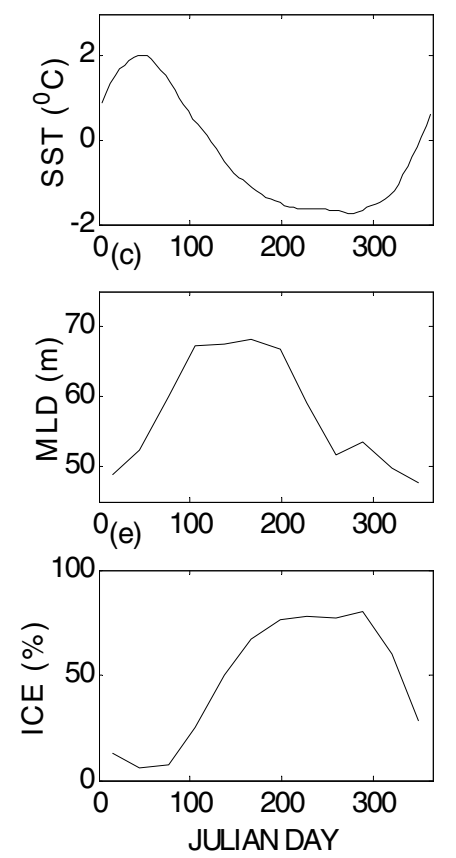

(b)
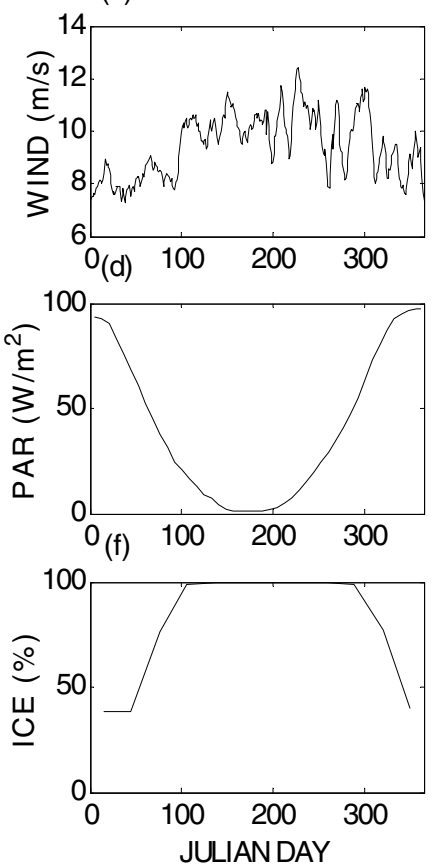

Fig. 2. Meteorological data: (a) surface temperature, (b) surface wind speed, (c) mixed layer depth, and (d) surface irradiance in PAR range, (e) ice cover at $65 \mathrm{~S}$, and (f) ice-cover at $67^{\circ} \mathrm{S}$. All the data have been smoothed to avoid numerical integration problems.

and Murphy, 1994). The phytoplankton community structure has been described by Wright and van den Enden (2000), who report maximum chlorophyll (Chl-a) concentrations during January-March in the range 1.0-3.4 $\mu \mathrm{g} \mathrm{L}^{-1}$. During the BROKE survey, macronutrients did not limit phytoplankton growth. Thermal stratification of the mixed layer was strongly correlated with high algal densities, with strong subsurface Chl maxima (at the pycnocline) observed. The mixed-layer depth determined both phytoplankton community composition and maximum algal biomass. Diatoms and haptophytes are the two main classes of phytoplankton that currently dominate the waters of the Southern Ocean. Haptophytes, including coccolithophorids and Phaeocystis antarctica (a noted DMS producer), were favoured by deep mixed layers, with diatoms dominating the more strongly stratified waters. The algal composition at the ice-edge was mixed, in part due to grazing. Algal abundance appeared to be controlled by salp and/or krill grazing. Nicol et al. (2000) note that krill were concentrated where winter sea-ice extent is maximal, whereas salps were located where the sea-ice is minimal.

Field data support the existence of seasonal DMS production in the Antarctic region. However, a large range in DMS concentrations has been reported in the open ocean, reflecting both seasonal and spatial variability (Berresheim, 1987; Fogelqvist, 1991; Curran et al., 1998). Blooms of coccolithophores and prymnesiophytes such as $P$. antarctica form a significant fraction ( 23\%) of the algal biomass (Waters et al., 2000). Concentrations of DMS in sea ice are reported to be very high (Turner et al., 1995), and may be responsible for elevated water concentrations during release from melt water (Inomata et al., 1997). Field measurements of dissolved DMS made in the study region have been summarised by Curran et al. (1998). DMS concentrations were variable in the open ocean during spring and summer (range 0-22 nM), with the higher values recorded in the seasonal ice zone and in Antarctic coastal waters. Zonally averaged monthly mean DMS concentrations for the Antarctic ocean have been 
estimated by Kettle et al. (1999) and Kettle and Andreae (2000).

\section{Methods}

\subsection{The general circulation model (GCM)}

The transient climate data were obtained from simulations with the Commonwealth Scientific and Industrial Research Organisation (CSIRO) coupled climate model (Gordon and O'Farrell, 1997) which includes ocean, atmosphere and sea-ice components. The horizontal resolution of the atmospheric model is $5.6 \mathrm{de}$ grees of longitude by 3.2 degrees of latitude (strictly it is a spectral model of R21 resolution) and it has nine vertical levels. The sea-ice model was described in O'Farrell (1997). The ocean model is based on the Bryan-Cox code (Cox, 1984) with 21 vertical levels. Further details of the ocean component are given in Gordon and O'Farrell (1997) and Hirst et al. (2000).

The coupled GCM was initialised using the final spin-up state of the atmosphere-ocean system which resulted from several thousand years of integration. The control integration used a constant equivalent $\mathrm{CO}_{2}$ concentration of $330 \mathrm{ppm}$ and was used to evaluate the statistical significance of trends predicted in the transient integration. The transient integration is subject to changing equivalent $\mathrm{CO}_{2}$ concentration as specified in the IPCC/ISP92a radiative forcing scenario following the prescription of Kattenberg et al. (1996) for the period from 1880 to 2086 (for details about this run and its evaluation, see Hirst, 1999).

A subset of the output from GCM simulations for the periods 1961-1970, 2029-2037 (doubled equivalent $\mathrm{CO}_{2}$ ) and 2078-2086 (tripled equivalent $\mathrm{CO}_{2}$ ) were obtained for the area indicated in Fig. 1. This includes ten (two latitudinal by five longitudinal) GCM horizontal grid points. With the exception of the mixed layer depth (MLD), the GCM output were spatially averaged over the 10 grid points. The GCM latitudinal grid points relevant to the study region are located at $62.1^{\circ} \mathrm{S}$ and $65.3^{\circ} \mathrm{S}$. The Antarctic coastline in the study region lies along $66-67^{\circ} \mathrm{S}$. The two latitudinal grid points used in the GCM may be characterised as 'ice-free' and 'coastal' Antarctic points. Because of marked differences in the GCM simulation of MLD at $62.1^{\circ} \mathrm{S}$ and $65.3^{\circ} \mathrm{S}$, the MLD data were averaged longitudinally. The GCM data were temporally averaged to derive monthly means of surface sea temperature, mixed-layer depth, sea-ice and cloud cover and daily averages of surface wind speed.

\subsection{DMS marine production model}

The DMS production model has been described previously in Gabric et al. (1993; 1999). We note that the DMS model and the GCM are not coupled, although the embedding of the sulfur model in the GCM is a longer-term aim. The version of the DMS model used here includes three biotic state variables, as well as dissolved DMSP and DMS. All state variables are vertically averaged over the oceanic mixed layer, where the MLD can vary throughout the year as prescribed by the output from the GCM simulation. The DMS model food web originally included five biotic state variables: a generic autotroph (phytoplankton), heterotrophic bacteria and three grazers, flagellates (bacterivores), large protozoa and macro-zooplankton. In contrast to our Barents Sea study (Gabric et al., 1999), very few data are available on the seasonal variability of bacteria and micro-grazers and their impact on the cycling of DMS(P) in the Antarctic Ocean. We have therefore simplified the food-web model in this analysis to include only a single heterotroph (micro- and macro-zooplankton). Importantly, the most influential model parameters as defined in a previous sensitivity analysis (Gabric et al., 2001) have been retained in the present formulation.

Walsh et al. (2001) speculate that a future decline of ice melt-induced stability of the water column may be associated with a shift in dominant food webs, from larger, sun-adapted diatoms grazed by euphausiids to smaller, shade-adapted flagellates consumed by salps. Although our simulations assume that climate change does not significantly modify the structure of the food web (Gabric et al., 1998; 2001), the potential change in ice-cover under enhanced greenhouse conditions suggests that Antarctic waters may be more susceptible to food-web shifts. We further discuss the potential for ecological change below.

Before attempting the climate-change simulations, the model was calibrated against contemporary (1990s) data on phytoplankton biomass (chlorophylla) and DMS. Since field data in the Antarctic ocean is very sparse outside the spring-summer period, satellite data from the SeaWiFS sensor was analysed in the study region for the period 1997-2001. This consisted of 8-d mean chlorophyll- $a$ concentration data. As the satellite sensor's optical penetration depth is approximately 25-30\% of the euphotic zone in oceanic waters (Smith, 1981), thus SeaWiFS is effectively registering near surface chlorophyll concentration. Consequently, deep chlorophyll maxima may not be detected, and 
the satellite may underestimate the true vertically integrated biomass. In order to calibrate the model against SeaWiFS chlorophyll- $a$, conversion from nitrogen to chlorophyll (CHL) units was made using a Redfield $\mathrm{C}: \mathrm{N}$ ratio of 5.7 (by weight) and a typical C:CHL ratio for Antarctic waters of 50 (Geider, 1987; Walsh et al., 2001).

Minimum-maximum ranges for each of the model parameters were estimated from the literature, and the calibration then proceeded in two stages: the food-web model was calibrated first using the mean annual cycle in satellite-derived algal biomass, and the sulfur species sub-model was then calibrated to the global DMS database of Kettle et al. (1999) and Kettle and Andreae (2000). Forcing data for the contemporary climate calibration (Fig. 2) were obtained from existing databases and satellite data. Parametric estimation for both calibrations was done using a Genetic Algorithm (GA) which is an efficient, non-derivative-based optimisation technique (Holland, 1975). The GA selects the set of parameter values giving the best fit to the data (in a least-squares sense), and results are given in Table 1, together with parameter values from previous studies.

As DMS is supersaturated in the surface ocean, the sea-to-air flux of DMS was computed as the product of the sea-to-air DMS transfer velocity and the sea-water
DMS concentration, $[\mathrm{DMS}]_{\mathrm{aq}}$,

$F_{\mathrm{DMS}}=k_{w}[\mathrm{DMS}]_{\mathrm{aq}}$.

The transfer velocity $k_{\mathrm{w}}$ was parameterised in terms of wind speed, $w$, and sea surface temperature according to the formulation of Liss and Merlivat (1986) as adapted for DMS by Gabric et al. (1995),

$k_{w}=\alpha 0.17 w$ for $w \leq 3.6$

$k_{w}=\beta(2.85 w-10.3)+0.61 \alpha$ for $3.6<w \leq 13$

$k_{w}=\beta(5.9 w-49.9)+0.61 \alpha \quad$ for $w>13$

with $\alpha=(600 / S c)^{2 / 3}$ and $\beta=(600 / S c)^{1 / 2}$. For a given gas, the Schmidt number $(S c)$ varies with water temperature, decreasing as the temperature increases. The dependence of Sc on sea surface temperature (SST) for DMS was experimentally derived by Saltzman et al. (1993) as,

$$
\begin{aligned}
S c= & 2674.0-147.12(S S T)+3.726(S S T)^{2} \\
& -0.038(S S T)^{3} .
\end{aligned}
$$

We note that empirical gas exchange - wind speed relationships have to be applied with caution, since they have an uncertainty of up to a factor of two.

\begin{tabular}{|c|c|c|c|c|c|}
\hline & Path & Units & This study & Barents Sea & Subantartic Southern Ocean \\
\hline$k_{4}$ & $\mathrm{Z}$ grazing rate (per indiv) on $\mathrm{P}$ & $\mathrm{m}^{3} \mathrm{mg} \mathrm{N}^{-1} \mathrm{~d}^{-1}$ & 0.026 & 0.01 & 0.0012 \\
\hline$k_{5}$ & Release rate of DMSP by $\mathrm{P}$ & $\mathrm{d}^{-1}$ & 0.0076 & 0.01 & 0.01 \\
\hline$k_{6}$ & Release rate of DMS by $\mathrm{P}^{\mathrm{A}}$ & $\mathrm{d}^{-1}$ & 0.0044 & 0.085 & 0.085 \\
\hline$k_{19}$ & $\mathrm{Z}$ specific $\mathrm{N}$ excretion rate & $\mathrm{d}^{-1}$ & 0.029 & 0.05 & 0.10 \\
\hline$k_{20}$ & Prop of $\mathrm{N}$ uptake excreted by $\mathrm{Z}$ & - & 0.37 & 0.4 & 0.4 \\
\hline$k_{21}$ & DMSP excretion rate by $\mathrm{Z}$ & $d^{-1}$ & 0.31 & 0.01 & 0.01 \\
\hline$k_{23}$ & Max rate of $\mathrm{N}$ uptake by $\mathrm{P}$ & $\mathrm{d}^{-1}$ & 0.99 & 0.27 & 0.9 \\
\hline$k_{24}$ & Half-sat const for $\mathrm{P}$ uptake of $\mathrm{N}$ & $\mathrm{mg} \mathrm{N} \mathrm{m}^{-3}$ & 19.1 & 12.6 & 13.9 \\
\hline$k_{27}$ & DMSP - DMS conversion rate & $\mathrm{d}^{-1}$ & 0.92 & 0.5 & 0.5 \\
\hline$k_{28}$ & DMS consumption rate by $\mathrm{B}^{\mathrm{A}}$ & $d^{-1}$ & 0.27 & 0.29 & 0.95 \\
\hline$k_{29}$ & Max DMS photo-oxidation rate & $\mathrm{d}^{-1}$ & 0.58 & 1.3 & 1.3 \\
\hline$k_{31}$ & DMSP consumption rate by B & $\mathrm{d}^{-1}$ & 0.12 & 0.53 & 1.0 \\
\hline$\gamma$ & phytoplankton $\mathrm{S}(\mathrm{DMSP})$ :N ratio & - & 0.36 & 0.04 & 0.3 \\
\hline$I_{\mathrm{s}}$ & Saturating irradiance ${ }^{a}$ & $\mathrm{~W} \mathrm{~m}^{-2}$ & 35 & 5.6 & $3-40$ \\
\hline$Z_{\mathrm{e}}$ & Euphotic depth & $\mathrm{m}$ & 92 & 15 & 67 \\
\hline$N_{0}$ & Total nitrogen & $\mathrm{mg} \mathrm{N} \mathrm{m}^{-3}$ & 3.08 & 5.0 & 6.8 \\
\hline
\end{tabular}

Table 1. Values of parameters used in the Antarctic simulations, with values used in previous simulations

All contemporary parameter values other than $I_{\mathrm{S}}$ have been derived by calibration.

$k_{4}, k_{19}, k_{20}, k_{23}, k_{24}$ and $N_{0}$ values were derived by fitting model phytoplankton to SeaWiFS chlorophyll; $k_{5}, k_{6}, k_{27}, k_{28}$, $k_{29}, k_{31}$ and $\gamma$ values were derived by fitting model DMS to Kettle DMS.

${ }^{\mathrm{a}} I_{\mathrm{s}}$ value obtained from Walsh et al. (2001) and $Z_{\mathrm{e}}$ from BROKE survey data. 
Although other formulations of the sea-to-air DMS flux exist (e.g. Wanninkhof, 1992), the Liss and Merlivat parameterisation used here has provided excellent estimates of DMS flux in the Subantarctic Southern Ocean (Ayers et al., 1995). The calculation of $k_{w}$ in the seasonal ice zone poses special difficulties, since DMS release from sea-ice during melting or breakup is well documented, and ice algae have also been shown to be significant producers of DMS and DMSP in the polar oceans (Kirst et al., 1991; Levasseur et al., 1994). We assume that DMS ventilation can only occur in ice-free waters, which is likely to be a lower bound on the true flux. Thus, the computed DMS transfer velocity was scaled by the percentage of ice-free water as predicted by the GCM. For the climate-change simulations, the GCM meteorological forcings were used. As GCM output did not include irradiance in the photosynthetic range, and there was very little change in GCM simulated short-wave radiation or cloud cover, the contemporary PAR seasonal cycle was used.

Phytoplankton growth is assumed to be affected by nutrient availability, light and temperature, the socalled multiplicative growth model (Platt et al., 1977). The specific nutrient uptake rate, $\mu$, is thus given by

$$
\mu(t)=V_{\mathrm{N}}(t) R_{\mathrm{L}}(t) R_{\mathrm{T}}(t)
$$

where $V_{\mathrm{N}}\left(\mathrm{h}^{-1}\right)$ is the nitrogen-specific nutrient uptake rate following standard Michaelis-Menten kinetics, and $R_{\mathrm{L}}$ and $R_{\mathrm{T}}$ are dimensionless light and temperature limitation coefficients (both $\leq 1$ ), respectively.

Light limitation of phytoplankton growth rate may be modelled using a number of formulations (e.g. Steele, 1962; Platt et al., 1980). We ignore any physiological effects of radiation in the UV-B range. Here we have chosen the relationship given by Smith (1936) as it involves a single parameter,

$$
R_{\mathrm{L}}=P / P_{\max }=\left(I / I_{\mathrm{s}}\right) / \sqrt{1+\left(I / I_{\mathrm{s}}\right)^{2}}
$$

where $P$ is the gross photosynthetic rate, $P_{\max }$ the maximum photosynthetic rate, $I$ the irradiance (PAR) at a particular depth, and $I_{\mathrm{s}}$ the saturating irradiance as defined by Talling (1957), which is species dependent (Raven and Richardson, 1986). During summer the phytoplankton community consists of a mix of diatoms and dinoflagellates, and we assume a average value of $I_{\mathrm{s}}$ of $35 \mathrm{~W} \mathrm{~m}^{-2}$ (Walsh et al., 2001, and references cited therein).

The average light limitation may be computed by integrating $R_{\mathrm{L}}$ over the mixed-layer depth; however, a very good approximation (to within $15 \%$ ) is obtained by substituting the depth-averaged irradiance for $I$ in eq. (5). The average irradiance $I_{\mathrm{av}}$ over the mixed layer depth, $Z_{\mathrm{m}}$, is given by

$I_{\mathrm{av}}=\frac{I_{0}}{k Z_{\mathrm{m}}}\left[1-\mathrm{e}^{-k Z_{\mathrm{m}}}\right]$

where $I_{0}$ is the surface irradiance, and $k$ the total attentuation coefficient, calculated as

$k=k_{0}+k_{\mathrm{p}} \mathrm{CHL}$

with $k_{0}$ the specific attenuation due to clear water and coloured dissolved organic matter $\left(0.05 \mathrm{~m}^{-1}\right)$, and $k_{\mathrm{p}}$ $\left[0.03 \mathrm{~m}^{-1}\left(\mathrm{mgChl} \mathrm{m}^{-3}\right)^{-1}\right]$ is due to the water column algal concentration, CHL (Walsh, 2001).

The temperature limitation coefficient is based on the relationship between the maximum specific growth rate and temperature derived by Eppley (1972):

$R_{\mathrm{T}}=\mathrm{e}^{0.063\left(T-T_{\max }\right)}$

where $T$ is the mixed layer bulk temperature in ${ }^{\circ} \mathrm{C}$ (assumed to be equal to the sea-surface temperature), and $T_{\max }$ the maximum annual temperature, at which we assume maximum specific growth rate is achieved. As discussed by Eppley (1972), the temperature at which optimal growth rate occurs is species dependent; however, Valiela (1995) notes there is often a poor correlation between ambient sea temperature and a species's physiological temperature response. We have assumed that over decadal timescales the phytoplankton species composition gradually adapts to the simulated increase in temperature. However, as noted above, a reduction in sea-ice extent may contribute to a change in foodweb structure. As far as our DMS model simulation is concerned, the main variables of interest are temperature, wind speed, PAR and MLD. We note that any future changes in ocean salinity through changes in precipitation will be implicitly accounted for via the changes in MLD. Any changes in vertical mixing rates (upwelling) are also partially implicit in the change in MLD.

The sulfur submodel formulation assumes that DMS and DMSP production and consumption follow firstorder kinetics. Modelled sinks for DMS include photochemical oxidation, microbial consumption and ventilation to the atmosphere. DMS photo-oxidation, which is a maximum at the surface, is scaled by the ratio of surface to average mixed layer irradiance. Photooxidation consequently varies diurnally and seasonally with changes in incident solar radiation and the MLD. 
The DMS model was forced using the GCM simulated time series of sea-surface temperature, wind speed, cloud cover, sea-ice and mixed layer depth over the period 1961-2086. In order to obtain a baseline for comparison, the DMS model was also run using the forcings as simulated in a 120-yr GCM control integration (constant $\mathrm{CO}_{2}$ concentration). As there is considerable interannual variability in both the GCM forcings and the DMS model predictions, decadal mean results are presented for three periods: 'current' conditions (1991-2000), and equivalent $\mathrm{CO}_{2}$ doubling (2028-2037) and tripling (2071-2080), relative to preindustrial levels.

\section{Results and discussion}

\subsection{Contemporary 1991-2000 simulations}

Initial ranges for the model parameters in Table 1 were obtained either from the literature or the BROKE survey data. The GA then searched this parameter space for the values that provided the best fit to the SeaWiFs CHL data (Fig. 3). A strong seasonal cycle in phytoplankton is evident with highest biomass achieved in December and January. The data gap during winter is due to shortened day-length combined with higher cloud and sea-ice cover. Variability in biomass is high, reflecting both the patchiness expected over such a large oceanic area, and the interannual variability present in the 4-yr SeaWiFS record.

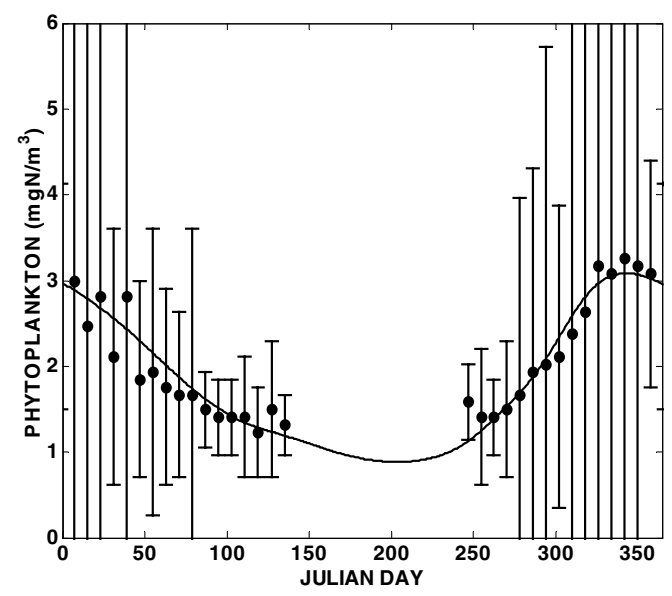

Fig. 3. Model prediction (line) vs. SeaWiFS chlorophyll concentrations (circles, with error bars of \pm 1 standard deviation). Standard errors of the means are within the circles.

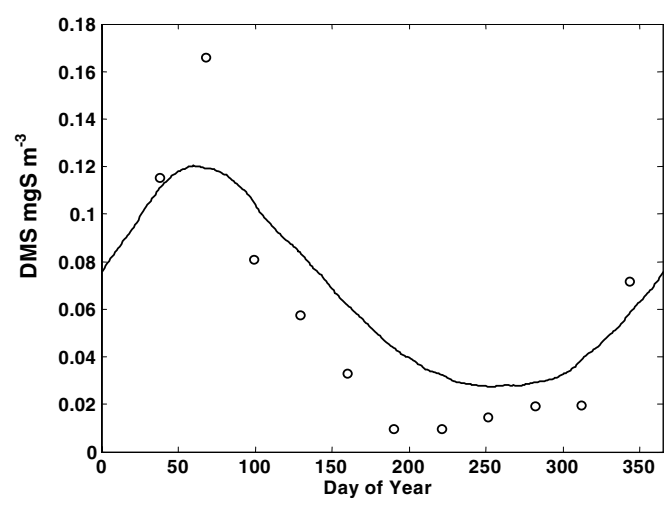

Fig. 4. Model predicted contemporary aqueous DMS concentration (solid line), and DMS concentration predicted by the Kettle et al. (1999) interpolation (circles).

However, the large number of data points available results in a very small standard error (high confidence) in the mean CHL. Results of the model calibration against the annual cycle in phytoplankton biomass are shown in Fig. 3. The model fit to the mean satellite data is extremely good.

The results of the DMS calibration are given in Fig. 4. The modelled cycle provides a very good fit to the data, particularly considering the Kettle et al. (1999; 2000) data for this latitude were zonal averages, and that due to a lack of observations, Kettle et al. set the DMS winter values arbitrarily to $0.3 \mathrm{nM}$. The peak DMS concentration is predicted to succeed the phytoplankton peak by over a month.

The predicted sea-to-air DMS flux cycle is given in Fig. 5. The flux is highest in late summer through autumn $\left(0.23 \mathrm{mgS} \mathrm{m}{ }^{-2} \mathrm{~d}^{-1} \equiv 7.1 \mu \mathrm{mol} \mathrm{m} \mathrm{m}^{-2} \mathrm{~d}^{-1}\right)$, and broadly tracks the cycle in DMS concentration. Interestingly, the flux cycle displays a characteristic bimodal summer peak, which has also been noted in the climatological DMS flux calculations done by Kettle and Andreae (2000). As the DMS concentration cycle is quite smooth, the double peak in flux is due to the combined effects of changes in windpeed, SST and MLD (Figs. 2a-c) on the DMS flux. Field data on non-sea-salt sulfate and MSA aerosols at three coastal Antarctic sites (Neumayer, Dumont d'Urville and Halley) were reported by Minikin et al. (1998). The concentrations of both sulfur species exhibited a regular and strong seasonal cycle with maxima from December to March and minima from May to September (MSA; 2-4; nss-sulfate; $17-50 \mathrm{ng} \mathrm{m}^{-3}$ ), which is consistent with our model predictions of DMS flux. 


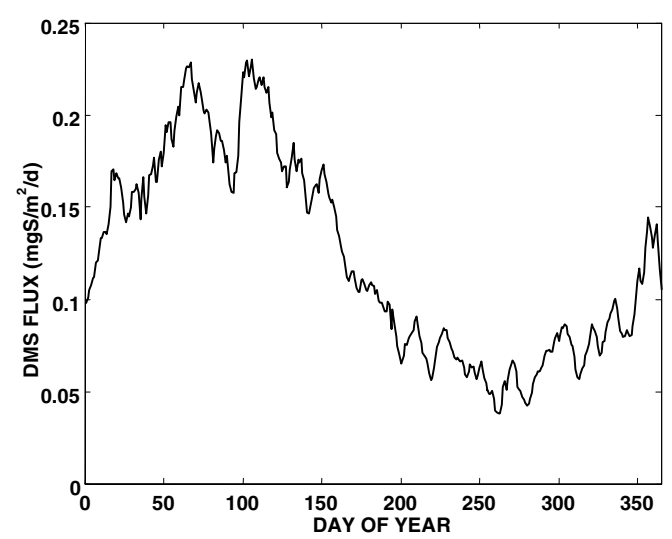

Fig. 5. Model predicted contemporary (1992-2001) annual cycle in DMS sea-to-air flux.

\subsection{GCM forced simulations}

A careful analysis of the GCM control integration (constant $\mathrm{CO}_{2}$ ) over the period 1800-2300 indicated some interdecadal variability (noise), but, importantly, no evidence of climate drift. Because of the GCM's coarse horizontal resolution, complex hydrodynamic features such as fronts or upwellings, e.g. the Antarctic divergence, in the $60-65^{\circ} \mathrm{S}$ latitudinal band are not accurately resolved.

The GCM outputs for SST, cloud cover, ice cover, surface wind speed and MLD are shown in Fig. 6 at the beginning of the time series and for the approximate times of equivalent $\mathrm{CO}_{2}$ doubling (2033) and tripling (2086) relative to pre-industrial levels. The GCM simulates an SST increase of about $0.5^{\circ} \mathrm{C}$ for the period of doubled $\mathrm{CO}_{2}$ and $1.3{ }^{\circ} \mathrm{C}$ for the period of tripled $\mathrm{CO}_{2}$ (Fig. 6a). These increases are fairly uniform throughout the annual cycle. By 2086 temperatures are sim- ulated to remain above $0{ }^{\circ} \mathrm{C}$ throughout the year. The GCM simulates little change in surface wind speed over the 120-yr period; however, seasonality in wind speed is more pronounced compared to the contemporary data (Fig. 6b). Winds are stronger during the austral winter.

The GCM simulates ice-free waters at $62.1^{\circ} \mathrm{S}$ throughout the period of the simulation. The change in ice cover at $65.3^{\circ} \mathrm{S}$ (Fig. 6c) is most pronounced during summer and autumn, with a relative decrease by 2086 of about $15-20 \%$. As the change is most significant during the phytoplankton growth season, there is a strong potential for a future shift in foodweb structure under enhanced greenhouse conditions.

The GCM simulates a strong shoaling of the MLD at $62.1^{\circ} \mathrm{S}$ during the austral winter-spring by 2086 (Fig. 7a); however, the trend is not monotonic over the 126-yr period. The counter-intuitive deepening of the winter-spring MLD at 2033 is most likely due to the climate change signal being affected by noise at this latitude and time period. By 2086 the climate change signal in MLD has strengthened and is much greater than noise. The MLD displays a strong seasonality at $62.1^{\circ} \mathrm{S}$. Although the spring MLD has shallowed by 2086 , it is still quite deep ( $150 \mathrm{~m}$ ), and this change is unlikely to impact greatly on primary production or DMS emissions. Interestingly, the GCM predicts little change in the MLD at $62.1^{\circ} \mathrm{S}$ during the austral summer.

In contrast to the ice-free zone, the mixed layer at $65.3^{\circ} \mathrm{S}$ does not display much seasonality. The GCM simulates a decrease in MLD of about $10 \%$ at $65.3^{\circ} \mathrm{S}$ by 2086. The decrease in MLD is monotonic over the $120-y r$ period and fairly uniform throughout the year. By 2086, the summer MLDs are similar throughout the study region. A change in ice-cover at $65.3^{\circ} \mathrm{S}$ will
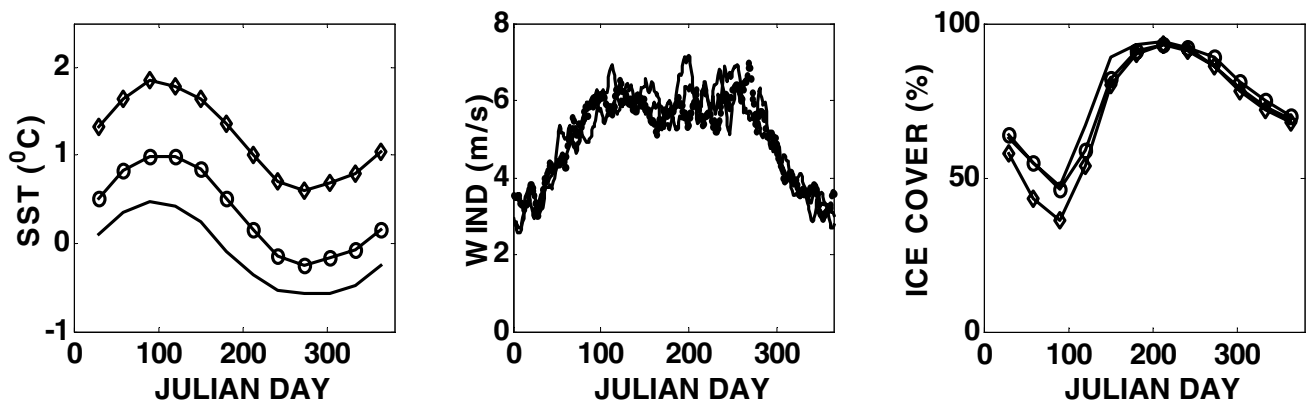

Fig. 6. Temporal trends in the GCM simulated forcings of sea surface temperature, surface wind speed and ice-cover at $65.3^{\circ} \mathrm{S}$ for the periods 1961-1969 (solid line), 2029-2037 (circles) and 2078-2086 (diamonds).

Tellus 55B (2003), 5 

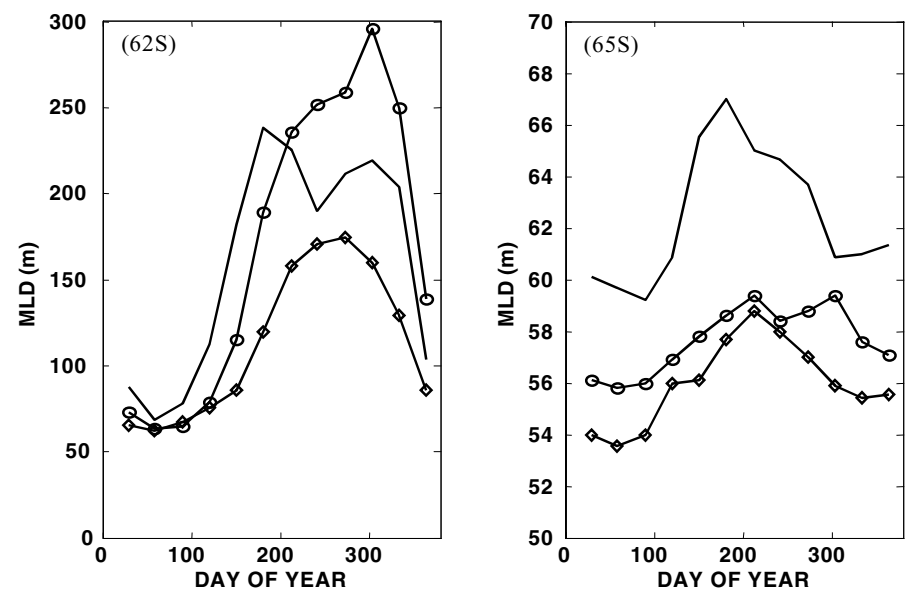

Fig. 7. GCM simulated MLD at $62.1^{\circ} \mathrm{S}$ and $65.3^{\circ} \mathrm{S}$, for the periods $1961-1969$ (solid line), 2029-2037 (circles) and 20782086 (diamonds).

affect the MLD, which is partly determined by the presence of melt water. During December-January, ice-cover $(\sim 70 \%)$ is fairly constant over the 120 -yr simulation; however, by 2086 there is a more rapid loss of ice cover during the January-April period. This suggests a greater production of melt-water during the summer-autumn season, with the possibility of increased water column stability during this period. By 2086, the GCM also simulates a general increase in precipitation at these latitudes, which would be another factor contributing to water column stabilization (Hirst, 1999).

\subsection{Trends in the DMS production cycle and annual cumulative flux}

As the model predictions are quite different in the ice-free ocean compared to the seasonal ice zone further south, we shall discuss the results at $62.1^{\circ} \mathrm{S}$ and $65.3^{\circ} \mathrm{S}$ separately. We note that the GCM simulated non-monotonic trend in MLD at $62.1^{\circ} \mathrm{S}$ at 2033 (due to noise) has also affecting the other predicted variables.

Ice-free zone at $62.1^{\circ} \mathrm{S}$ The predicted change in the phytoplankton and DMS cycles under warming is shown in Figs. 8a and b. The change in the DMS flux cycle is given in Fig. 8c. The phytoplankton peak occurs earlier in the year under enhanced greenhouse conditions, and the DMS cycle shows a similar shift. As can be seen from Fig. 7, the main agent for the change in annual integrated flux $(21 \%)$ by 2086 (Table 4) seems to be shoaling of the mixed layer, confirming the important role of the MLD in the DMS cycle, which has been hypothesised by Simó and Pedrós-Alió (1999).
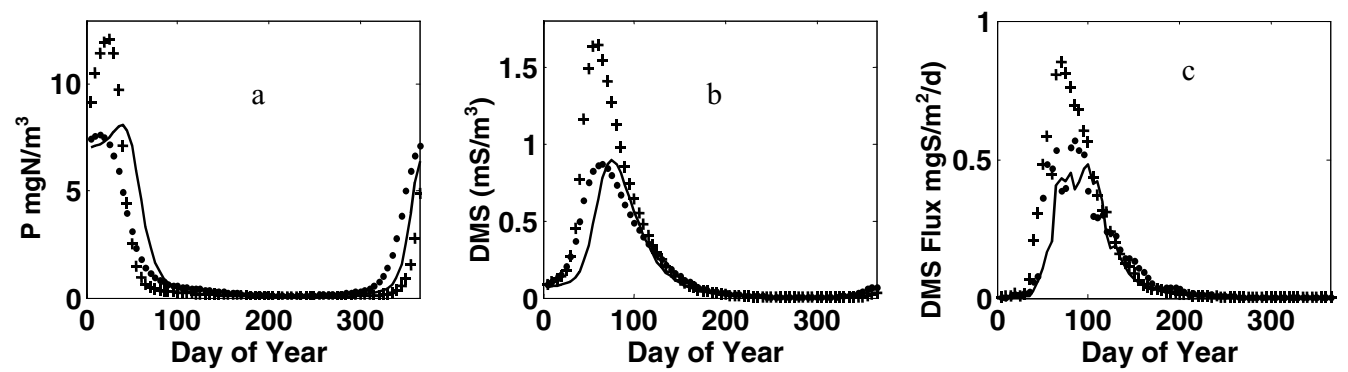

Fig. 8. Predicted trends in (a) phytoplankton and (b) DMS concentrations (c) DMS flux in ice-free zone at $62.1^{\circ} \mathrm{S}(1961-1969$ solid line, 2029-2037 plus signs, 2078-2086 dots). 

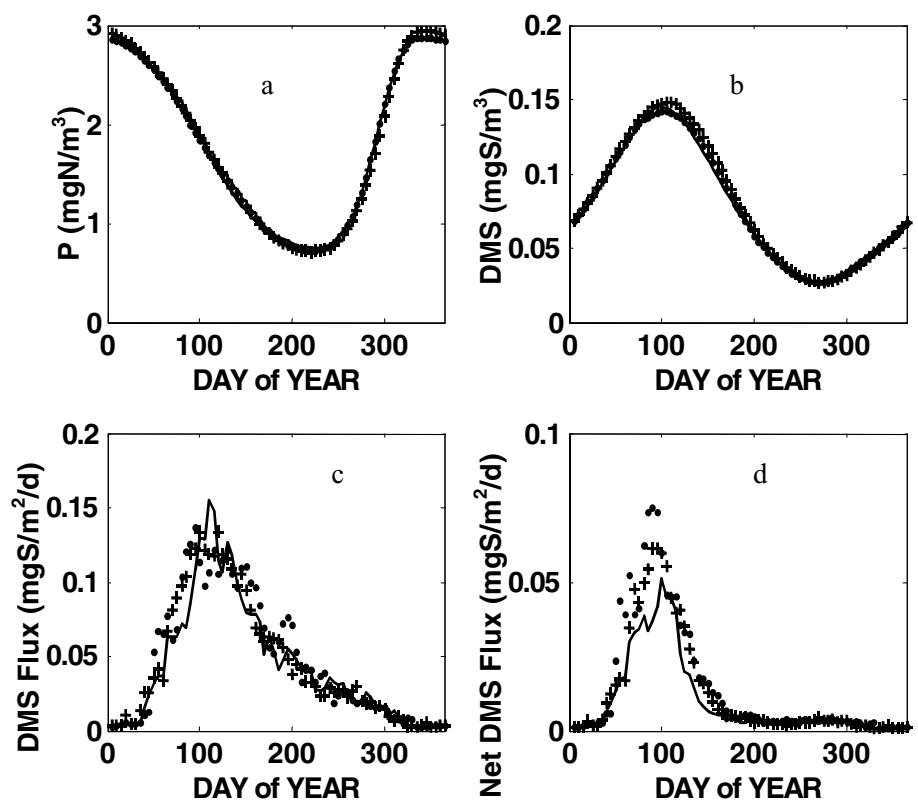

Fig. 9. Model predicted (a) phytoplankton and (b) DMS concentrations, (c) DMS flux in the seasonal ice zone at $65.3^{\circ} \mathrm{S}$, (d) net DMS flux in seasonal ice zone after adjustment for change ice cover at $65.3^{\circ} \mathrm{S}$ under enhanced greenhouse conditions: 1961-1969 (solid line), 2029-2037 (plus signs) and 2078-2086 (dots).

Seasonal ice zone at $65.3^{\circ} \mathrm{S}$ The annual cycles in phytoplankton and DMS are shown in Figs. 9a and b, with the DMS flux cycle given in Figs. 9c. The adjustment to the flux for ice-cover is shown in Fig. 9d. As the MLD changes only marginally at this latitude, the main reason for the large increase $(46 \%)$ in integrated flux (Table 4) is the loss of ice-cover during late summer by 2086. Analysis of a larger set of the CSIRO Mk2 GCM simulations for the broader Antarctic ocean suggests this characteristic is also apparent for some, but not all, other areas of the Antarctic sea ice zone. We note that the magnitude of the predicted change in DMS flux across the study region is much greater than our previous findings in the Subantarctic, which estimated the flux increase for a tripling of $\mathrm{CO}_{2}$ to be less than 10\% (Gabric et al. 1998; 2001).

\subsection{Potential for foodweb structural change}

The connection between large-scale biogeochemical changes and ecological shifts in the marine biosphere of the Antarctic Southern ocean is important for the understanding of both past and future global climate change. The modelled change in DMS flux we have described above is largely the result of phys- ical changes in the water column. However, the net ventilation of DMS is the result of whole food-web interactions, with traits such as nonlinearity and multiple feedbacks that are typical of a complex system. Clearly, global warming has the potential to induce ecological changes, the key question being: will this enhance or mitigate the impact of the GCM-simulated physical changes on DMS production?

We note that physics and biology may interact in complicated ways. For example, Slezak et al. (2001) report that solar radiation can significantly alter the microbial metabolism of DMS and DMSP. The higher average light regime resulting from a shallowing of the MLD in summer may thus both decrease the microbial consumption of DMS(P) and increase photolytic loss of DMS.

Paleoecological studies can give us a clue to the potential for future climate-change induced ecological shifts. For example, the glacial iron hypothesis conjectures that an increase in aeolian iron-deposition to the Southern Ocean during the last glacial maximum (LGM) stimulated primary and export production (Kumar et al., 1995) resulting in a decrease in atmospheric $p \mathrm{CO}_{2}$ (Martin, 1990). Evidence suggests that diatoms and coccolithophorids did not play a 
Table 2. DMS model equations given in terms of fluxes defined in Table 3

\begin{tabular}{|c|c|}
\hline State variable (units) & Model equation \\
\hline$P$ : generic autotroph $\left(\mathrm{mg} \mathrm{N} \mathrm{m}^{-2}\right)$ & $\frac{\mathrm{d} P}{\mathrm{~d} t}=f_{61}-f_{15}-f_{1 w}$ \\
\hline$Z:$ micro/mesozooplankton $\left(\mathrm{mg} \mathrm{N} \mathrm{m}^{-2}\right.$ ) & $\frac{\mathrm{d} Z}{\mathrm{~d} t}=f_{15}-f_{56}-f_{5 w}$ \\
\hline$N$ : dissolved inorganic nitrogen $\left(\mathrm{mg} \mathrm{N} \mathrm{m}^{-2}\right)$ & $\frac{\mathrm{d} N}{\mathrm{~d} t}=f_{56}-f_{61}-f_{62}$ \\
\hline DMSP: dissolved DMSP [mg S(DMSP) $\mathrm{m}^{-2}$ ] & $\frac{\mathrm{dDMSP}}{\mathrm{d} t}=f_{17}+f_{47}+f_{57}-f_{78}-f_{72}$ \\
\hline DMS: dissolved DMS [mg S(DMS) $\mathrm{m}^{-2}$ ] & $\frac{\mathrm{dDMS}}{\mathrm{d} t}=f_{18}+f_{78}-f_{82}-f_{8 w}-f_{8 a}$ \\
\hline
\end{tabular}

Table 3. Model flux definitions

\begin{tabular}{lll}
\hline Flux & \multicolumn{1}{c}{ Formulation } & \multicolumn{1}{c}{ Description } \\
\hline$f_{15}$ & $k_{4} P Z$ & Grazing of P by zooplankton (Z) \\
$f_{17}$ & $k_{5} \gamma P$ & Release of DMSP by P \\
$f_{18}$ & $\gamma k_{6} P$ & Release of DMS by P, $\gamma$ is the DMSP cell content \\
$f_{1 w}$ & $k_{7} P$ & Respiration and sedimentation of P below thermocline \\
$f_{56}$ & $k_{19} Z+k_{20}\left[f_{15}+f_{45}\right]$ & Excretion of dissolved N by Z \\
$f_{57}$ & $\gamma k_{21} Z$ & Excretion of DMSP by Z \\
$f_{5 w}$ & $k_{22} f_{56}+k_{32} Z$ & Sedimentation and export of Z \\
$f_{61}$ & $R_{\mathrm{L}} R_{\mathrm{T}} k_{23} P N /\left[N+k_{24}\right]$ & Uptake of dissolved N by P \\
$f_{62}$ & $k_{25} B N /\left[N+k_{26}\right]$ & Uptake of dissolved N by B \\
$f_{72}$ & $k_{31} \times \mathrm{DMSP}$ & Biodegradation of DMSP \\
$f_{78}$ & $k_{27} \times \mathrm{DMSP}$ & Conversion of DMSP to DMS in water column \\
$f_{82}$ & $k_{28} \times \mathrm{DMS}$ & Biodegradation of DMS \\
$f_{8 w}$ & $k_{29} \times \mathrm{DMS}$ & Photo-oxidation sink for DMS \\
$f_{8 a}$ & $k_{\mathrm{w}} \times \mathrm{DMS}$ & Ventilation of DMS to atmosphere \\
\hline
\end{tabular}

Table 4. Comparison of predicted annual mean concentration and flux of DMS to the atmosphere

\begin{tabular}{|c|c|c|c|c|}
\hline $\begin{array}{l}\text { Forcing } \\
\text { scenario }\end{array}$ & $\begin{array}{l}\text { Mean DMS conc. } \\
\quad\left(\mathrm{mg} \mathrm{S} \mathrm{m}^{-3}\right)\end{array}$ & $\begin{array}{l}\text { Annual DMS flux } \\
\left(\mathrm{mg} \mathrm{S} \mathrm{m}^{-2} \mathrm{yr}^{-1}\right)\end{array}$ & $\begin{array}{l}\text { Annual DMS flux } \\
\text { after adjustment for } \\
\text { ice }\left(\mathrm{mg} \mathrm{S} \mathrm{m}^{-2} \mathrm{yr}^{-1}\right)\end{array}$ & $\begin{array}{l}\% \text { Change in flux } \\
\text { relative to } 1960 \mathrm{~s}\end{array}$ \\
\hline Contemporary $\left(62.1^{\circ} \mathrm{S}\right)$ & 0.066 & 44.6 & & \\
\hline Contemporary $\left(65.3^{\circ} \mathrm{S}\right)$ & 0.66 & 44.6 & 28.0 & \\
\hline GCM 1961-1969 $\left(62.1^{\circ} \mathrm{S}\right)$ & 0.16 & 34.0 & 34.0 & \\
\hline GCM 2029-2037 $\left(62.1^{\circ} \mathrm{S}\right)$ & 0.28 & 54.5 & 54.5 & $+60 \%$ \\
\hline GCM 2078-2086 $\left(62.1^{\circ} \mathrm{S}\right)$ & 0.20 & 41.1 & 41.1 & $+21 \%$ \\
\hline GCM $1961-1969\left(65.3^{\circ} \mathrm{S}\right)$ & 0.078 & 16.1 & 3.7 & \\
\hline GCM 2029-2037 $\left(65.3^{\circ} \mathrm{S}\right)$ & 0.080 & 16.9 & 4.7 & $+28 \%$ \\
\hline GCM $2078-2086\left(65.3^{\circ} \mathrm{S}\right)$ & 0.078 & 17.3 & 5.354 & $+46 \%$ \\
\hline
\end{tabular}

prominent role in this increased production (De La Rocha et al., 1998; Howard and Prell, 1994). One hypothesis that can explain the increased production, as well as evidence for higher levels of MSA, in ice cores during glacial times (Legrand et al., 1991) is that the algal bloom-forming species responsible for the atmospheric $p \mathrm{CO}_{2}$ drawdown was a high DMS-producing organism that has left no sedimentary record
(DiTullio et al., 2000; Martin, 1992; Moore et al., 2000). Increased abundance of the colonial haptophyte $P$. antarctica (a high DMSP producer) during the LGM would be consistent with the accumulated evidence.

Dissolved Fe concentrations $(0.3-0.5 \mathrm{nM})$ are sufficient to initiate the austral spring bloom in the Ross Sea, but Fe becomes limiting $(0.1 \mathrm{nM})$ in the early 
austral summer (Sedwick et al., 2000). Diatom blooms frequently occur in the marginal ice zones where Fe concentrations are elevated (Sedwick and DiTullio, 1997). Blooms of colonial P. antarctica begin early (late October) during the austral spring in the Ross Sea but then collapse during the late spring or early austral summer as Fe is depleted. It is unknown what the regulating mechanism is for the demise of these $P$. antarctica blooms.

Recent evidence suggests that $P$. antarctica growth in the Ross Sea is enhanced in regions with deeper mixed layers compared to diatom growth which thrives in shallower mixed layers (Arrigo et al., 1999a; 1999b). Dominance of $P$. antarctica during the early spring bloom period in the Ross Sea is concomitant with higher Fe availability (Sedwick et al., 2000). It is also evident that $P$. antarctica's superior photosynthetic parameters (relatively high photosynthetic rates at very low irradiances) imparts a physiological advantage to this species relative to diatoms. For instance, $P$. antarctica blooms remove about twice as much $\mathrm{CO}_{2}$ per mole of $\mathrm{PO}_{4}$ compared with diatom blooms (Arrigo et al., 1999a; 1999b). In addition, in the Ross Sea, colonial Phaeocystis antarctica blooms are not grazed (Caron et al., 2000) and can contribute significantly to export production (DiTullio et al., 2000).

Hence, an ecological shift in algal species that alters the relative proportions of diatoms (low DMSP producers) and $P$. antarctica is likely to have a significant impact on both the carbon and sulfur cycles, especially considering the high DMS levels (16$32 \mathrm{mmol} \mathrm{m} \mathrm{m}^{-2}$ ) in $P$. antarctica blooms (DiTullio et al., 2000) and the percentage of DMSP carbon synthesized relative to total carbon (Matrai and Keller, 1994).

The net biological impact of a warming Southern Ocean is difficult to predict because of the interplay between the various organisms constituting the microbial food-web (Marchant et al., 2001). Changes in the distribution of some organisms for which temperature responses are known can be predicted. Thus, warming should lead to the southerly extension of the range of coccolithophorids and the cyanobacterium Synechoccocus and a contraction of the range of Parmales, a class of phytoplankton found principally in the coldest polar waters (Franklin and Marchant, 1995; Zelinski, 1997). Increasing water temperature would also be expected to led to an increase in bacterial activity, as most Antarctic marine bacteria are living below their optimal temperatures, although this may be reduced somewhat due to the stronger light regime in a shallower mixed layer, as noted above. Such a change in community composition would be expected to alter the production and microbial utilization of DMSP/DMS. A southward spread of coccolithophorids would mean more DMSP being produced, although an increase in bacterial activity may lead to increased utilization of DMS.

Increasing sea temperature would be expected to lead to a lessening of the amount of sea-ice and the extent and duration of the seasonal ice zone. Changes in sea-ice extent, are also likely to influence whether krill or salps are more abundant (Nicol et al., 2000). Up to 100-fold variations of both krill (Euphausia superba) and salp (Salpa thompsoni) adult populations have been found in relation to changing ice cover (Walsh et al., 2001). A loss of ice favours salps, which will then dominate the macrozooplankton community. These metazoa feed differently and can influence the community composition of protists (Loeb et al., 1997).

Detailed ecological model simulations by Walsh et al. (2001) suggest that a likely future consequence of reduced ice cover in coastal regions of the Antarctic Southern Ocean, may be a decline of both diatom stocks and of larval survival of krill and copepods. Without adult krill to disperse prymnesiophyte colonies as smaller-size food for protozoans, blooms of Phaeocystis may be promoted. This again suggests that, in this region, Phaeocystis will benefit from global warming, and on balance, the increase in DMS flux predicted above is unlikely to be mitigated by ecological shifts.

\section{Conclusions}

Coupled atmosphere-ocean GCM simulations of temperature, cloud, wind speed and MLD under enhanced greenhouse conditions have been used to force a regional DMS production model in the Eastern Antarctic Southern Ocean. The GCM simulation was run in transient mode over the time period 19612086, and suggested significant trends in temperature, mixed layer depth and ice cover in the SIZ, but no significant trend in the other meteorological variables. Of particular note was the GCM simulation of no significant changes in cloud cover and total short-wave radiation. Given the hypothesised connection between DMS derived aerosols, cloud albedo and the earth's radiative budget, future studies should 
examine the possibility of embedding the DMS model in the GCM.

The predicted rate of increase in DMS flux is much greater than estimated previously at lower latitudes and suggests that significant future change in the sulfur budget may occur at higher latitudes. Based on our present understanding of the Antarctic food web, this is not likely to be mitigated by an decreased abundance of DMS-producing Phaeocystis.

Following the methodology of Gabric et al. (1998), and assuming an empirical relation between DMS flux and $\mathrm{CCN}$ concentration in the Antarctic atmosphere similar to that measured in the Subantarctic, we estimate that a mean enhancement of $33 \%$ in DMS flux and a mean summer flux of $5 \mu \mathrm{mol} \mathrm{m} \mathrm{m}^{-2} \mathrm{~d}^{-1}$ would lead to $\mathrm{a}-1.7 \pm 0.5 \mathrm{~W} \mathrm{~m}^{-2}$ radiative forcing (combined direct and indirect). By way of comparison, the climate model simulations suggest a tripling of equivalent $\mathrm{CO}_{2}$ concentration contributes an increase in long-wave radiative forcing of the troposphere of $\sim 6.9 \mathrm{~W} \mathrm{~m}^{-2}$, consistent with other climate model simulations (Houghton et al., 1996). Thus the mean DMS flux perturbation in this polar region represents a negative feed-back strength of about $25 \%$. When compared with our previous Subantarctic simulations, our results highlight the likely regional variability in the response of DMS emissions to climate change.

\section{Acknowledgments}

We thank the SeaWiFS Project (Code 970.2) and the Distributed Active Archive Centre (Code 902) at the Goddard Space Flight Centre, Greenbelt, MD 20771, for the production and distribution of the SeaWiFS data, respectively. These activities are sponsored by NASA's Mission to Planet Earth Program (http://seawifs.gsfc.nasa.gov). The Quikscat/SeaWinds and Advanced Very High Resolution Radiometer data were obtained from the NASA Physical Oceanography Distributed Active Archive Centre at the Jet Propulsion Laboratory, California Institute of Technology (http://podaac.jpl.nasa.gov). The SSMI data was provided by the Defense Meteorological Satellite Program, National Oceanic and Atmospheric Administration, US Department of Commerce (http://www.ncdc.noaa.gov). The NODC (Levitus) World Ocean Atlas 1994 data were provided by the NOAA-CIRES Climate Diagnostics Centre, Boulder, Colorado (http://www.cdc.noaa.gov/). The World Ocean Atlas 1998 was supplied by the Ocean Climate Laboratory, National Oceanographic Data Centre, National Oceanic and Atmospheric Administration, US Department of Commerce (http://www.nodc.noaa.gov). We gratefully acknowledge the financial assistance of a ASAC Grant from the Australian Antarctic Division and an Australian Research Council Large Grant.

\section{REFERENCES}

Arrigo, K. R., DiTullio, G. R., Dunbar, R. B., Robinson, D. H., Van Woert, M., Worthen, D. L. and Lizotte, M. 1999a. Phytoplankton taxonomic variability in nutrient utilization and primary production in the Ross Sea. J. Geophys. Res. 105, 8827-8846.

Arrigo, K. R., Robinson, D. H., Worthen D. L., Dunbar, R. B., DiTullio, G. R., VanWoert, M. and Lizotte, M. 1999b. Phytoplankton community structure and the drawdown of nutrients and $\mathrm{CO}_{2}$ in the Southern Ocean. Science 283, 365367.

Ayers, G. P. and Gras, J. L. 1991. Seasonal relationship between cloud condensation nuclei and aerosol methanosulphonate in marine air. Nature 353, 834-835.

Ayers, G. P., Gillet, R. W., Ivey, J. P., Schafer, B. and Gabric, A. J. 1995. Short-term variability in marine atmospheric dimethylsulfide concentration. Geophys. Res. Lett. 22, 2513-2516.

Berresheim, H. 1987. Biogenic sulfur emissions from the subantarctic and Antarctic Oceans. J. Geophys. Res. 92, 13 245-13 262.

Boyd, P. W. and Law, C. S. 2001. The Southern Ocean Iron
RElease Experiment (SOIREE)-introduction and summary. Deep Sea Res. II, 48, 2425-2438.

Boyer, T. P. and Levitus, S., 1994. Quality control and processing of historical temperature, salinity and oxygen data. NOAA Technical Report NESDIS 81. 65 pp.

Caron, D., Dennett, M. R., Lonsdale, D. J., Moran, D. M. and Shalapyonok, L. 2000. Microzooplankton herbivory in the Ross Sea. Deep-Sea Res. 47, 3249-3272.

Charlson, R. J., Lovelock, J. E., Andreae, M. O. and Warren, S. G. 1987. Oceanic phytoplankton, atmospheric sulphur, cloud albedo and climate. Nature 326, 655661 .

Cox, M. D. 1984. A primitive equation, 3-dimensional model of the ocean. GFDL Ocean Group Tech. Rep. No. 1, GFDL/Princeton University, Princeton University, Princeton, N.J., 141 pp.

Curran, M. A. J., Jones, G. B. and Burton, H. 1998. Spatial distribution of dimethylsulfide and dimethylsulfoniopropionate in the Australasian sector of the Southern Ocean. J. Geophys. Res. 103, 16 677-16 689. 
De La Rocha, C. L., Brzezinski, M. A., DeNiro, M. J. and Shemesh, A. 1998. Silicon isotope composition of diatoms as an indicator of past oceanic change. Nature $\mathbf{3 9 5}, 680$ 683.

DiTullio, G. R., Grebmeir, J., Lizote, M. P., Arrigo, K. R., Robinson, D. H., Leventer, A., Barry, J., Van Woert, M. and Dunbar, R. B. 2000. Rapid and early export of Phaeocystis antarctica blooms to deep water and sediments of the Ross Sea, Antarctica. Nature 404, 595-598.

El-Sayed, S. Z. 1988. Seasonal and interannual variabilities in Antarctic phytoplankton with reference to krill distribution. In: Antarctic Ocean and resources variability (ed. D. Sahrhage), Springer-Verlag, New York, 101-119.

Eppley, R. W. 1972. Temperature and phytoplankton growth in the sea. Fish. Bull. 70, 1063-1085.

Fogelqvist, E. 1991. Dimethylsulphide (DMS) in the Weddell Sea surface and bottom water. Marine Chem. 35, 169-177.

Foley, J. A., Taylor K. E. and Ghan, S. J. 1991. Planktonic dimethylsulfide and cloud albedo: an estimate of the feedback response. Climate Change 18, 1-15.

Franklin, D. C. and Marchant, H. J. 1995. Parmales in sediments of Prydz Bay East Antarctica: a new biofacies and paleoenvironmental indicator of cold water deposition? Micropaleontology 41, 89-94.

Gabric, A. J., Murray, C. N., Stone, L. and Kohl, M. 1993. Modelling the production of dimethylsulfide during a phytoplankton bloom. J. Geophys. Res. 98, C12, 2280522816.

Gabric, A. J, Ayers, G. P. and Sander, G. C. 1995. Independent marine and atmospheric model estimates of the sea-air flux of dimethylsulfide in the Southern Ocean. Geophys. Res. Lett. 22, 3521-3524.

Gabric, A. J., Ayers, G. P., Murray C. N. and Parslow, J. 1996. Use of remote sensing and mathematical modelling to predict the flux of dimethylsulphide to the atmosphere in the Southern Ocean. Adv. in Space Res. 18, 117-128.

Gabric, A. J., Whetton, P., Boers, R. and Ayers, G. P. 1998. The impact of GCM predicted climate change on the air-tosea flux of dimethylsulphide in the subantarctic Southern Ocean. Tellus 50B, 388-399.

Gabric, A. J., Matrai, P. and Vernet, M. 1999. Modelling the production of dimethylsulphide during the vernal bloom in the Barents Sea. Tellus 51B, 919-938.

Gabric, A. J., Whetton, P. and Cropp, R. 2001. Dimethylsulphide production in the subantarctic Southern Ocean under enhanced greenhouse conditions. Tellus 53B, 273-287.

Gabric, A. J., Cropp, R., Ayers, G. P., McTainsh, G. and Braddock, R. 2002. Coupling between cycles of phytoplankton biomass and aerosol optical depth as derived from SeaWiFS time series in the Subantarctic Southern Ocean. Geophys. Res. Lett. 29, No. 7, art no. 1112.

Geider, R. J. 1987. Light and temperature dependence of the carbon to chlorophyll $a$ ratio in microalgae and cyanobacteria: Implications for physiology and growth of phytoplankton. New Phyto. 106, 1-34.

Gordon, H. G. and O'Farrell, S. P. 1997. Transient climate change in the CSIRO coupled model with dynamic sea ice. Mon. Weather Rev. 125, 875-907.
Hirst, A. C. 1999. The Southern Ocean response to global warming in the CSIRO coupled ocean atmosphere model: Special issue on Global Change. Environ. Model. Software 14, 227-242.

Hirst, A. C., O'Farrell, S. P. and Gordon, H. B. 2000. Comparison of a coupled ocean-atmosphere model with and without oceanic eddy-induced advection. Part I: Ocean spin up and control integrations. J. Climate 13,139-163.

Holland, J. H. 1975. Adaptation in Natural and Artificial Systems. University of Michigan Press, Michigan, USA.

Houghton, J. T., Meira Filho, L. G., Callander, B. A., Harris, N., Kattenberg, A. and Varney, S. K. 1996. Climate change 1995: contribution of working group 1 to the second assessment report of the IPCC. Cambridge University Press, Cambridge, $572 \mathrm{pp}$.

Howard, W. R. and Prell, W. L. 1994. Late quaternary $\mathrm{CaCO}_{3}$ production and preservation in the Southern Ocean: Implications for oceanic and atmospheric carbon cycling. Paleocenography 9, 453-482.

Inomata, Y., Matsunaga, K., Hayashi, M., Osada, K. and Iwasaka, Y. 1997. Volatile sulfur compounds in the atmosphere and seawater during Antarctic cruise of Shirase. Polar Meteorology and Glaciology, No. 11, Natl. Inst. Polar Res., Tokyo.

Kattenberg, A., Giorgi, F., Grassl, H., Meehl, G. A., Mitchell, F. B., Stouffer, R. J., Tokioka, T., Weaver, A. J. and Wigley, T. M. L. 1996. Climate models - Projections of future climate. In: Climate Change 1995: The science of climate change (eds. J. T. Houghton), Cambridge University Press, Cambridge, 285-357.

Keller, M. D., Bellows, W. K. and Guillard, R. L. 1989. Dimethyl sulfide production in marine phytoplankton. In: Biogenic sulfur in the environment (eds. E. S. Saltzman and W. J. Cooper), American Chemical Society, Washington, DC.

Kettle, A. J. et al. 1999. A global database of sea surface dimethylsulfide (DMS) measurements and a procedure to predict sea surface DMS as a function of latitude, longitude and month. Global Biogeochem. Cycles 13, 399-444.

Kettle, A. J. and Andreae, M. O. 2000. Flux of dimethylsulphide from the oceans: a comparison of updated data sets and flux models. J. Geophys. Res. 105, 26 793-26 808.

Kiene, R. P. and Bates, T. S. 1990. Biological removal of dimethylsulfide from seawater. Nature 345, 702-705.

Kirst, G. O., Thiel, C., Wolff, H., Nothnagel, J., Wanzek, M. and Ulmke R. 1991. Dimethylsulfoniopropionate (DMSP) in ice algae and its possible biological role. Marine Chem. 35, 381-388.

Kumar, N., Anderson, R. F., Mortlock, R. A., Froelich, P., Kubik, P., Dittrich-Hannen, B. and Suter, M. 1995. Increased biological productivity and export production in the glacial Southern Ocean. Nature 378, 675-680.

Lawrence, M. G. 1993. An empirical analysis of the strength of the phytoplankton-dimethylsulfide-cloudclimate feedback cycle. J. Geophys. Res. 98, 20 663-20 673.

Leck, C., Larsson, U., Bågander, L. E., Johansson, S. and Hajdu, S. 1990. DMS in the Baltic Sea. Annual variability 
in relation to biological activity. J. Geophys. Res. 95, 33533363.

Legrand, M., Feniet-Saigne, C., Saltzman, E., Germain, C., Barkov, N. and Petrov, V. 1991. Ice-core record of oceanic emissions of dimethylsulfide during the last climate cycle. Nature 350, 144-146.

Levasseur, M., Gosselin, M. and Michaud, S. 1994. A new source of dimethyl sulfide for the Arctic atmosphere. Marine Biol. 121, 381-387.

Levasseur, M., Michaud, S., Egge, J., Cantin, G., Nejstgaard, J. C., Sanders, R., Fernandez, E., Solberg, P. T., Heimdal, B. and Gosselin, M. 1996. Production of DMSP and DMS during a mesocosm study of an Emiliana huxleyi bloom: influence of bacteria and Calanus finmarchicus grazing. Marine Biol. 126, 609-618.

Lewis, M. R. 1995. Coastal Zone Color Scanner on Nimbus and Sea-Viewing Wide Field-0f-View sensor on Seastar. In: Oceanographic applications of remote sensing (eds. M. Ikeda and F. W. Dobson). CRC Press, Boca Raton, FL, 167-181.

Liss, P. S. and Merlivat, L. 1986. Air - sea gas exchange rates: Introduction and synthesis. In: The role of air-sea exchange in geochemical cycling (ed. P. Buat-Menard), Reidel, Hingham, MA, 113-127.

Loeb, V., Siegel, V., Holm-Hansen, O., Hewitt, R. P., Fraser, W. R., Trivelpiece, W. Z. and Trivelpiece, S. G. 1997. Effects of sea-ice extent and krill or salp dominance on the Antarctic food web. Nature 387, 897-900.

Marchant, H. and Murphy, E. J. 1994. Interactions at the base of the Antarctic food web. In: Southern Ocean Ecology: The BIOMASS Perspective (ed. S. El-Sayed), Cambridge University Press, New York, 267-285.

Marchant, H. J., Davidson, A. T. and Wright, S. W. 2001. Antarctic marine microorganisms and climate change: impacts and feedbacks. Ocean and Polar Res. 23, 401-410.

Martin, J. H. 1990. Glacial-interglacial $\mathrm{CO}_{2}$ change: the iron hypothesis. Paleoceanography 5, 1-13.

Martin, J. H. 1992. Iron as a limiting factor in oceanic productivity. In: Primary productivity and biogeochemical cycles in the sea (eds. P. Falkowski and A. D. Woodhead), Plenum Press, New York, 123-137.

Matrai, P. A. and Keller, M. D. 1994. Total organic sulfur and dimethylsulfoniopropionate (DMSP) in marine phytoplankton: Intracellular variations. Marine Biol. 119, 6168.

Meszaros, E. 1988. On the possible role of the biosphere in the control of atmospheric clouds and precipitation. Atmos. Environ. 22, 423-424.

Minikin, A., Legrand, M., Hall, J., Wagenbach, D., Kleefeld, C., Wolff, E., Pasteur, E. C. and Ducroz, F. 1998. Sulfur-containing species (sulfate and methanesulfonate) in coastal Antarctic aerosol and precipitation. J. Geophys. Res. 103, 10 975-10990.

Moore, J. K., Abbott, M. R., Richman, J. R. and Nelson, D. M. 2000. The Southern Ocean at the last glacial maximum: a strong sink for atmospheric carbon dioxide. Global Biogeochem Cycles 14, 455-475.

Nicol, S., Pauly, T., Bindoff, N. L., Wright, S., Thiele, D.,
Hosie, G. W., Strutton, P. G. and Woehler, E. 2000. Ocean circulation off east Antarctica affects ecosystem structure and sea-ice extent. Nature 406, 504-507.

O'Farrell, S. P. 1997. Sensitivity study of a dynamical sea ice model. The effect of external stresses and land boundary conditions on ice thickness distribution. J. Geophys. Res. 103, 15 751-15 782.

Platt, T., Denman, K. L. and Jassby, A. D. 1977. Modeling the productivity of phytoplankton, In: The Sea, vol. 6 (ed. E. D. Goldberg), New York, Wiley, 807-856.

Platt, T., Gallegos, C. L. and Harrison, W. G. 1980. Photoinhibition of photosynthesis in natural assemblages of marine phytoplankton. J. Marine Res. 38, 687-701.

Raven, J. A. and Richardson, K. 1986. Marine environments. In: Photosynthesis in contrasting environments (eds.N. R. Bakes and S. P. Long), Elsevier Science Publishers, Amsterdam.

Sarmiento J. L., Hughes, T. M. C., Stouffer, R. J. and Manabe, S. (1998) Simulated response of the ocean carbon cycle to anthropogenic climate warming. Nature 393, 245-249.

Saltzman, E. S., King, D. B., Holmen, K. and Leck, C. 1993. Experimental determination of the diffusion coefficient of dimethylsulfide in water. J. Geophys. Res. 98, 16 481-16 486.

Sedwick, P. N. and DiTullio, G. R. 1997. Regulation of algal blooms in Antarctic shelf waters by the release of iron from melting sea ice. Geophys. Res. Lett. 24, 2515-2518.

Sedwick, P. N., DiTullio, G. R. and Mackey, D. J. 2000. Iron and manganese in the Ross Sea, Antarctica: seasonal iron limitation in Antarctic shelf waters. J. Geophys. Res. 105, $11321-11336$.

Shaw, G. E. 1983. Bio-controlled thermostasis involving the sulfur cycle. Clim. Change 5, 297-303.

Simó, R. and Pedrós-Alió, C. 1999. Role of vertical mixing in controlling the oceanic production of dimethylsulphide. Nature 402, 396-399.

Simo, R. 2001. Production of atmospheric sulfur by oceanic plankton: biogeochemical, ecological and evolutionary links. Trends Ecol. Evol. 16, 287-294.

Skerratt, J. H., Nichols, P. D. and Burton, H. 1995. Seasonal and interannual changes in planktonic biomass and community structure in eastern Antarctica using signature lipids. Marine Chem. 51, 93-113.

Slezak, D., Brugger, A. and Herndl, G. J. 2001. Impact of solar radiation on the biological removal of dimethylsulfoniopropionate and dimethylsulfide in marine surface waters. Aquatic Microb. Ecol. 25, 87-97.

Smith, E. L. 1936. Photosynthesis in relation to light and carbon dioxide. Proc. Natl. Acad. Sci. USA 22, 504-511.

Smith, R. C. 1981. Remote sensing and the depth distribution of ocean chlorophyll. Marine. Ecol. 5, 359-361.

Steele, J. H. 1962. Environmental control of photosynthesis in the sea. Limnol. Oceanogr. 7, 137-150.

Talling, J. F. 1957. Photosynthetic characteristics of some freshwater plankton diatoms in relation to underwater radiation. New Phytol. 56, 29-50.

Turner, A. M., Nightingale, P. D., Broadgate, W. and Liss, P. S. 1995. The distribution of dimethylsulphide and 
dimethylsulphoniopropionate in Antarctic waters and sea ice. Deep-Sea Res. II, 42, 1059-1080.

Valiela, I. 1995. Marine ecological processes. 2nd edn., Springer-Verlag, New York.

Walsh, J. J., Dieterle, D. A. and Lenes, J. 2001. A numerical analysis of carbon dynamics of the Southern Ocean phytoplankton community: the roles of light and grazing in effecting both sequestration of atmospheric $\mathrm{CO}_{2}$ and food availability to larval krill. Deep-Sea Res. I, 48, 1-48.

Wanninkhof, R. 1992. Relationship between wind speed and gas exchange over the ocean. J. Geophys. Res. 97, 73737382 .

Waters, R. L., van den Enden, R. and Marchant, H. J.
2000. Summer microbial ecology off East Antarctica (80$\left.150^{\circ} \mathrm{E}\right)$ : protistan community structure and bacterial abundance. Deep-Sea Res. II, 47, 2401-2435.

Wright, S. W. and van den Enden, R. L. 2000. Phytoplankton community structure and stocks in the Eastern Antarctic marginal ice zone (BROKE survey, JanMar 1996) determined by CHEMTAX analysis of HPLC pigment signatures. Deep Sea Res. 47, 23632400.

Zielinski, U. 1997. Parmales species (siliceous marine nanoplankton) in surface sediments of the Weddell Sea, Southern Ocean: indicators for sea ice environment. $M a-$ rine Micropaleol. 32, 387-395. 